\section{The effect of anionic impurities on the sorption extraction of molybdenum from leaching solutions}

Y.N. Panova, Y.O. Abzhan*, A.K. Zhussupova

Al-Farabi Kazakh National University, Almaty, Kazakhstan

*E-mail: yenglikabzhan@gmail.com
Molybdenum is one of the most important uranium-related metals. In the ores of many deposits, the molybdenum content is comparable to the uranium content. The processing of complex uranium-molybdenum ores is based on the methods of acid and soda autoclave leaching, in which uranium and molybdenum pass into solution. At the present time, the associated extraction of molybdenum by the sorption method has been developed and introduced. In this case, the capacity of ion exchangers with respect to uranium and molybdenum substantially depends on the salt composition of the medium

The aim of this work is to study the sorption of molybdenum from a carbonate leach solution on BD-301G-I anion exchange resin in the presence of the most common anionic impurities in industrial solutions. Studies of the sorption capacity of anion exchange resin with respect to molybdenum were carried out under static conditions with stirring of the solution with the sorbent during eight hours. Sorption of molybdenum was carried out from carbonate solutions with the corresponding given concentrations of impurity components. According to the results of studies, it was found that, according to the strength of the depressing effect, the considered anions arranged in the following row: $\mathrm{S}_{2} \mathrm{O}^{2-}>\mathrm{NO}^{-}>\mathrm{Cl}^{-}>\mathrm{SO}^{2-}>\mathrm{HCO}^{-}>\mathrm{CO}^{2-}>\mathrm{PO}^{3-}$.

The results of this study can be used to further study the sorption of molybdenum from real industrial solutions of carbonate leaching.

Keywords: molybdenum; carbonate solution; sorption; sorption capacity; anionic impurities.

\section{Тұндырғыш ерітінділерден молибденнің сорбциялық экстракциясына анионды қоспалардың әсері}

Е.Н. Панова, Е.Ө. Абжан", А.К. Жусупова

Әл-Фараби атындағы Қазақ ұлттық университеті, Алматы, Қазақстан *E-mail: yenglikabzhan@gmail.com

\section{Влияние анионных примесей на сорбционное извлечение молибдена из растворов выщелачивания}

Е.Н. Панова, Е.Ө. Абжан", А.К. Жусупова

Казахский национальный университет имени аль-Фараби, Алматы, Казахстан *E-mail: yenglikabzhan@gmail.com
Молибден уранның ең маңызды ілеспе металдардың бірі болып табылады. Көптеген кен орындарының рудаларында молибден мөлшері уран құрамымен салыстырылады. Уран-молибденнің күрделі кендерін өңдеу уран мен молибденнің ерітіндіге өтетін қышқылдық және сода автоклавты сілтілеу әдісіне негізделген. Қазіргі уақытта молибденді сорбциялық әдіспен ілеспе алу әзірленіп, енгізілді. Бұл жағдайда ион алмастырғыштардың уран мен молибденге қатысты сыйымдылығы ортаның тұз құрамына байланысты болады.

Бұл жұмыстың мақсаты ең көп таралған аниондық қоспалардың қатысуымен BD-301G-I күшті негіздегі анионитте карбонатты сілтісіздендіру ерітіндісінен молибденнің сорбциясын зерттеу болып табылады. Аниониттің молибденге қатысты сорбциялық сыйымдылығын зерттеу сегіз сағат аралығында сорбентпен ерітіндіні араластыру кезінде статикалық жағдайларда жүргізілді. Молибден сорбциясы карбонатты ерітінділерден қоспалы компоненттердің тиісті берілген концентрацияларымен жүзеге асырылды. Зерттеу нәтижелері бойынша, депрессиялық әсердің күшіне сәйкес қарастырылған аниондарды келесі орналау қатары анықталды: $\mathrm{S}_{2} \mathrm{O}_{3}{ }^{2-}>\mathrm{NO}_{3}^{-}>\mathrm{Cl}^{-}>\mathrm{SO}_{4}{ }^{2-}>\mathrm{HCO}_{3}{ }^{-}>\mathrm{CO}_{3}{ }^{2-}>\mathrm{PO}_{4}{ }^{3-}$.

Осы зерттеудің нәтижелерін карбонатты сілтілендірудің нақты өндірістік ерітінділерінен молибденнің сорбциясын одан әрі зерттеу үшін қолдануға болады.

Түйінді сөздер: молибден; карбонатты ерітінді; сорбция; сорбциялық сыйымдылық; анионды қоспалар.

Молибден является одним из наиболее важных сопутствующих урану металлов. В рудах многих месторождений содержание молибдена сравнимо с содержанием урана В основе переработки комплексных уран-молибденовых руд лежат методы кислотного и содового автоклавного выщелачивания, при котором уран и молибден переходят в раствор. В настоящее время разработано и внедрено попутное извлечение молибдена сорбционным методом. При этом емкость ионитов по отношению к урану и молибдену существенно зависит от солевого состава среды.

Целью настоящей работы является изучение сорбции молибдена из карбонатного раствора выщелачивания на анионите BD-301G-I в присутствиинаиболее распространенных в промышленных растворах анионных примесей. Исследования сорбционной емкости анионитапоотношениюкмолибденупроведенывстатическихусловияхприперемешивании раствора с сорбентом в течение восьми ч. Сорбция молибдена осуществлялась из карбонатных растворов с соответствующими заданными концентрациями примесных компонентов. По результатам исследований установлено, что по силе депрессирующего действия рассмотренные анионы распологаются в следующий ряд: $\mathrm{S}_{2} \mathrm{O}_{3}{ }^{2-}>\mathrm{NO}_{3}{ }^{-}>\mathrm{Cl}^{-}>\mathrm{SO}_{4}{ }^{2-}>$ $\mathrm{HCO}_{3}^{-}>\mathrm{CO}_{3}{ }^{2-}>\mathrm{PO}_{4}^{3-}$.

Результаты данного исследования могут быть использованы при дальнейшем изучении сорбции молибдена из реальных промышленных растворов карбонатного выщелачивания.

Ключевые слова: молибден; карбонатный раствор; сорбция; сорбционная емкость; анионные примеси. 


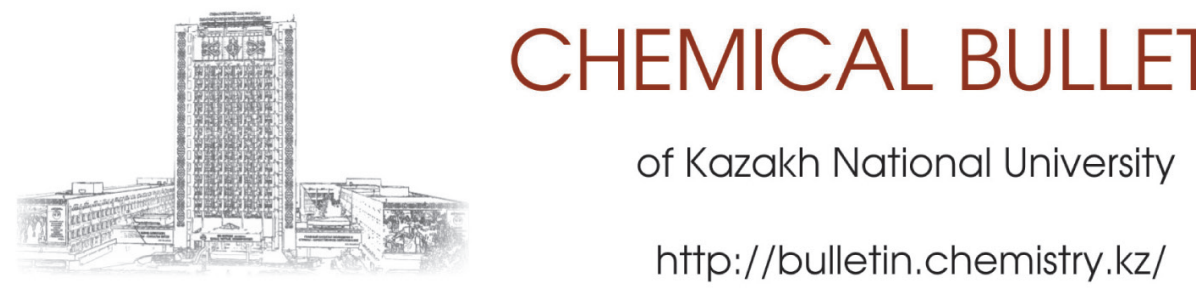

\title{
The effect of anionic impurities on the sorption extraction of molybdenum from leaching solutions
}

\author{
Y.N. Panova ${ }^{(D)}$, Y.O. Abzhan* (D) A.K. Zhussupova \\ Al-Farabi Kazakh National University, Almaty, Kazakhstan \\ "E-mail: yenglikabzhan@gmail.com
}

\section{Introduction}

The Republic of Kazakhstan is one of the world leaders in uranium mining, and and more than $10 \%$ of its world reserves located in its territory. In the process of uraniumore leaching, molybdenum, rhenium, scandium, vanadium, selenium, rareearth elements and other elements also pass into the solution [1]. Nowadays, not enough attention is paid to the extraction of useful associated components. Improving the complexity of the use of raw materials remains an important problem in the uranium industry [2].

Great interest is given to the complex processing of molybdenum-containing uranium ores $[4,5]$. The solution to this problem is largely determined by the development of hydrometallurgical processes of joint leaching and extraction of both components from the solutions.

Production of uranium from ores with a low content is carried out by the hydrometallurgical method using sulfuric acid or carbonate-bicarbonate solutions. Uranium is extracted from productive solutions mainly by the sorption method using various synthetic ion-exchange resins [6-8]. The main methods which are used to isolate molybdenum solutions also include ion exchange, solvent extraction, membrane separation and precipitation [9-12]. The fast kinetics of metabolism and the effective desorption of soda-chloride solutions make the sorption method of extracting molybdenum from carbonate media very attractive.

It is known that carbonate leaching is characterized by a fairly high selectivity relatively to the main components, but, nevertheless, in solutions obtained by extracting uranium and molybdenum from ore, the total salt content often reaches $50 \mathrm{~g} / \mathrm{l}$. The most common anionic impurities include carbonate and bicarbonate ions, sulfates, products of incomplete oxidation of sulfides - thiosulfates and polythionates, phosphates, arsenates, organic substances, etc. $[13,14]$. In industrial solutions, nitrate and chlorine ions also may be present, which are introduced into the process during the regeneration of the sorbent and as a result of the circulation of process water.

The high content of impurity anions in the solution leads to a decrease in the sorption capacity of ion exchangers for valuable components and an increase in the required number of sorption stages. From the foregoing, it follows that studying the effect of the content of various anions on the process of sorption extraction of molybdenum from leaching solutions is an urgent problem.

\section{Experiment}

In the present work, we studied the sorption of molybdenum from model leaching solutions with different contents carbonate and bicarbonate ions and other anions, which were considered as impurities. To prepare model solutions containing various anions, the corresponding sodium salts and ammonium molybdate were used. The concentrations of the main components and impurities were chosen taking into account their possible ratio in industrial solutions.

The promising macroporous anion exchange resin BD301G-I (made in China) was taken as a sorbent. The anion exchange resin was converted into the chlorine-ion form by treating it with a $2 \mathrm{~N}$ sodium chloride solution, which is acidified to $\mathrm{pH} 1.5$ with hydrochloric acid, after which the sorbent was washed with distilled water to a neutral medium and dried in air.

The study of sorption of molybdenum was carried out under static conditions with stirring of the solution. The duration of contact of the sorbent with the solution in all experiments was eight hours, which ensured the achievement of almost complete sorption equilibrium. The ratio of the sorbent sample in grams to the volume of solution in milliliters was 1:1000. 
At the end of the process, the sorbent was separated from the solution by filtration through a filter paper. Sorbent and filtrate (solution) were analyzed for the content of molybdenum by induction-coupled plasma with mass separation (ICP MS).

The sorption capacity of ion exchanger $A(\mathrm{mg} / \mathrm{g})$ was calculated by the formula:

$$
\mathrm{A}=\left(\mathrm{C}_{\text {init }}-\mathrm{C}_{\text {equil }}\right) \cdot \mathrm{V} / \mathrm{m} \text {, }
$$

where, $C_{\text {init }}$ - initial concentration of molybdenum in solution, $\mathrm{mg} / \mathrm{l} ; \mathrm{C}_{\text {equil }}$ - equilibrium concentration of molybdenum in solution, $\mathrm{mg} / \mathrm{l} ; \mathrm{V}$ - volume of test solution, $\mathrm{l} ; \mathrm{M}$ - mass of sorbent, $\mathrm{g}$.

\section{Results and Discussion}

One of the most important factors determining the most favorable conditions for the sorption extraction of molybdenum from alkaline solutions is the concentration of carbonate and bicarbonate ions. The sorption capacity of BD-301G-I anion exchange resin was studied according to molybdenum depending on the concentration of these ions in solution. Sorption was carried out from solutions with a molybdenum content of $0,4 \mathrm{~g} / \mathrm{l}$, carbonate and bicarbonate ions from 1 to $50 \mathrm{~g} / \mathrm{l}$.

The experimental data (Tables 1 and 2) show that the studied dependence is complex, especially for sorption from bicarbonate media.

The presence of a carbonate ion, even in small amounts, inhibits the sorption of molybdenum to a large extent. So, with an increase in the concentration of carbonate ions from 1 to $10 \mathrm{~g} / \mathrm{l}$, the sorption capacity of the anion exchange resin is almost halved. An increase in the concentration of bicarbonate ion to $5 \mathrm{~g} / \mathrm{l}$ has a relatively small effect on the absorption of molybdenum by anion exchange resin, then their depressive effect increases sharply. With an increase in the concentration of the bicarbonate ion from 5 to $25 \mathrm{~g} / \mathrm{l}$, the anion exchange rate decreases by $70 \%$, and at $50 \mathrm{~g} / \mathrm{l}$ the sorption of molybdenum is almost completely suppressed.

Thus, comparing the inhibitory effect of $\mathrm{CO}_{3}{ }^{2-}$ and $\mathrm{HCO}_{3}$ ions on the sorption of molybdenum in the technologically most widespread concentration range from 5 to $50 \mathrm{~g} / \mathrm{l}$, it should be noted that both ions significantly suppress the sorption of molybdenum. In addition, at an ion concentration of less than $25 \mathrm{~g} / \mathrm{l}$, the carbonate ion has a slightly more inhibitory effect, and at an ion concentration of more than $25 \mathrm{~g} / \mathrm{l}$, the depressant effect is more pronounced for bicarbonate ions.

Obviously, in the case of processing carbonate solutions for effective sorption of molybdenum by anion exchangers, the concentration of carbonate and bicarbonate ions should not exceed $10 \mathrm{~g} / \mathrm{l}$.

To study the effect of other anions on the sorption of molybdenum, we used a model solution containing $1 \mathrm{~g} / \mathrm{l}$ of molybdenum and $25 \mathrm{~g} / \mathrm{l}$ of carbonate ion.

Sulfate ion is, as a rule, an unavoidable impurity in
Table 1 - Effect of carbonate ion concentration on sorption of molybdenum

\begin{tabular}{ll}
\hline The concentration of carbonate ion, $\mathrm{g} / \mathrm{l}$ & $\mathrm{A}, \mathrm{mg} / \mathrm{g}$ \\
\hline 0,0 & 126,4 \\
1,0 & 120,0 \\
2,6 & 101,6 \\
5,1 & 85,6 \\
10,4 & 61,6 \\
15,0 & 56,8 \\
25,2 & 47,2 \\
50,0 & 32,8 \\
\hline
\end{tabular}

Table $\mathbf{2}$ - The effect of the concentration of bicarbonate ion on the sorption of molybdenum

\begin{tabular}{ll}
\hline The concentration of bicarbonate ion, $\mathrm{g} / \mathrm{l}$ & $\mathrm{A}, \mathrm{mg} / \mathrm{g}$ \\
\hline 0,0 & 126,4 \\
1,3 & 100,0 \\
3,7 & 98,9 \\
5,2 & 78,0 \\
10,3 & 56,8 \\
15,0 & 42,4 \\
25,3 & 23,2 \\
49,1 & 8,8 \\
\hline
\end{tabular}

solutions from carbonate leaching of uranium-molybdenum ores. Its main sources are sulfides, which are oxidized during leaching to sulfates, as well as insoluble sulfates, which can undergo an exchange decomposition process with soda ash.

Table 3 presents data illustrating the effect of the sulfate ion on the sorption of molybdenum by BD-301G-I anion exchange resin.

Table 3 - The effect of the concentration of sulfate ion on the sorption of molybdenum

\begin{tabular}{ll}
\hline The concentration of sulfate ion, $\mathrm{g} / \mathrm{l}$ & $\mathrm{A}, \mathrm{mg} / \mathrm{g}$ \\
\hline 0,0 & 73,0 \\
1,0 & 67,5 \\
2,0 & 61,5 \\
5,0 & 51,4 \\
10,0 & 39,0 \\
15,0 & 30,0 \\
25,0 & 21,0 \\
50,0 & 18,8 \\
\hline
\end{tabular}


As follows from the above data, a sharp drop in capacity by more than $50 \%$ is observed with an increase in the concentration of sulfate ion from 1 to $15 \mathrm{~g} / \mathrm{l}$. An increase in the concentration of sulfate ion in solution to $50 \mathrm{~g} / \mathrm{l}$ leads to a decrease in the sorption capacity of anion exchange resin by molybdenum by almost 4 times.

Further, the effect of thiosulfate ion on the sorption capacity of BD-301G-I anion exchange resin for molybdenum was studied. Thiosulfate ion can be formed during carbonate leaching as a product of the incomplete oxidation of sulfide minerals:

$2 \mathrm{MeS}_{2}+5 \mathrm{O}_{2}+6 \mathrm{Na}_{2} \mathrm{CO}_{3}+5 \mathrm{H}_{2} \mathrm{O} \rightarrow 2 \mathrm{Na}_{2} \mathrm{SO}_{4}+2 \mathrm{Me}(\mathrm{OH})_{2}+$ $\mathrm{Na}_{2} \mathrm{~S}_{2} \mathrm{O}_{3}+6 \mathrm{NaHCO}_{3}$

As can be seen from the data given in Table 4, the presence of thiosulfate ions in the solution to $1 \mathrm{~g} / \mathrm{l}$ reduces the capacity of anion exchange resin for molybdenum by 2 times, and a further increase in concentration to $10-15 \mathrm{~g} / \mathrm{l}$ almost completely suppresses the sorption ability of the studied anion exchange resin.

Among the most important technological impurities, we also considered phosphate ion. Table 5 shows data illustrating the effect of the phosphate ion on the sorption capacity of BD301G-I on molybdenum.

Phosphate ion, as follows from the data presented, to a much lesser extent than thiosulfate ion, depresses the sorption

Table 4 - Effect of the concentration of thiosulfate ion on the sorption of molybdenum

\begin{tabular}{ll}
\hline The concentration of thiosulfate ion, $\mathrm{g} / \mathrm{l}$ & $\mathrm{A}, \mathrm{mg} / \mathrm{g}$ \\
\hline 0,0 & 73,00 \\
0,6 & 42,8 \\
1,0 & 37,2 \\
5,0 & 14,3 \\
10,0 & 7,1 \\
15,0 & 4,6 \\
\hline
\end{tabular}

Table 5 - Effect of the concentration of phosphate ion on the sorption of molybdenum

\begin{tabular}{ll}
\hline The concentration of phosphate ion, $\mathrm{g} / \mathrm{l}$ & $\mathrm{A}, \mathrm{mg} / \mathrm{g}$ \\
\hline 0,0 & 73,0 \\
0,5 & 72,2 \\
0,7 & 70,0 \\
0,9 & 68,0 \\
1,2 & 67,6 \\
2,3 & 65,2 \\
4,3 & 64,0 \\
\hline
\end{tabular}

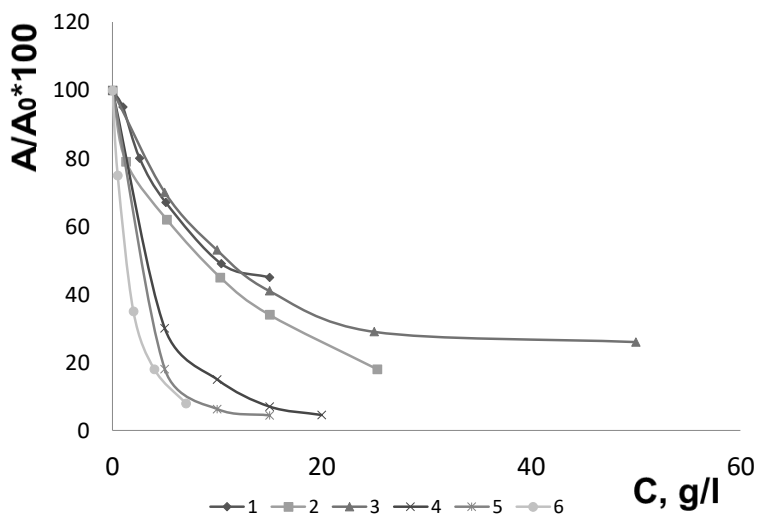

Figure 1 - The effect of impurities on the sorption capacity of anion exchange resin BD-301G-I on molybdenum: $1-\mathrm{CO}_{3}{ }^{2-}, 2$

$$
-\mathrm{HCO}_{3}, 3-\mathrm{SO}_{4}^{2-}, 4-\mathrm{Cl}^{-}, 5-\mathrm{NO}_{3}^{-}, 6-\mathrm{S}_{2} \mathrm{O}_{3}^{2}
$$

Table 6 - The effect of the concentration of chlorine and nitrate ions on the sorption of molybdenum

\begin{tabular}{llll}
\hline $\begin{array}{l}\text { The concentration } \\
\text { of chlorine ion, g/l }\end{array}$ & $\begin{array}{l}\mathrm{A}, \\
\mathrm{mg} / \mathrm{g}\end{array}$ & $\begin{array}{l}\text { The concentration of } \\
\text { nitrate ion, g/l }\end{array}$ & $\begin{array}{l}\mathrm{A}, \\
\mathrm{mg} / \mathrm{g}\end{array}$ \\
\hline 0,0 & 73,0 & 0,0 & 73,0 \\
1,0 & 47,9 & 1,0 & 35,4 \\
3,0 & 30,7 & 3,0 & 17,2 \\
5,0 & 22,4 & 5,0 & 13,5 \\
10,0 & 10,8 & 10,0 & 4,6 \\
15,0 & 4,95 & 15,0 & 3,2 \\
20,0 & 3,3 & 20,0 & 1,7 \\
\hline
\end{tabular}

of molybdenum and can cause difficulties only at high concentrations.

The possibility of the presence of chlorine and nitrate ions in carbonate solutions is associated with the use of the sodium salts of these ions as regenerating solutions.

Table 6 shows data showing the effect of chlorine and nitrate ions on the sorption of molybdenum by BD-301G-I anion exchange resin.

As follows from the data presented, even at a concentration of chlorine ion of 3-5 g/l, the sorption capacity of the ion exchanger for molybdenum drops 2-3 times. Nitrate ion has an even more pronounced depressant effect. In figure 1 it is given the dependence showing the change in the relative sorption capacity $A / A_{0}$ in percent of the anion exchange resin BD-301G-I in molybdenum on the concentration of the considered impurities. Sorption capacity of BD-301G-I anion exchange resin for molybdenum in a solution of ammonium molybdate that does not contain other anions is taken as $A_{0}$. This graph allows you to get a visual picture of the effect of various anions on the sorption of molybdate ions from carbonate solutions. 


\section{Conclusion}

Summarizing the data on the effect of depressing impurities on the sorption of molybdenum from carbonate media, it should be noted that of all the ions examined, the products of incomplete sulfur oxidation, thiosulfate ions, which are present even in small amounts in the solution, lead to the sharpest decrease in the sorption capacity of the studied anion exchange resin.

The accumulation in the system due to the circulation of circulating solutions of such impurities as chlorine and nitrate ions, the content of which in the amount of $5 \mathrm{~g} / \mathrm{l}$ reduces the capacity of molybdenum by 3.5-6 times, can lead to great complications in the process of sorption processing.

In the sorption extraction of molybdenum, the sulfate ion can also have a significant effect on the sorption properties of ion exchangers. The concentration of carbon and bicarbonate ions in the solution should not exceed $10-15 \mathrm{~g} / \mathrm{l}$.

As follows from the above data, in accordance with their inhibitory effect on the sorption of molybdenum, the considered impuritiescan be located in the following order: $\mathrm{S}_{2} \mathrm{O}_{3}{ }^{2-}>\mathrm{NO}_{3}{ }^{-}>\mathrm{Cl}^{-}>\mathrm{SO}_{4}{ }^{2-}>\mathrm{HCO}_{3}^{-}>\mathrm{CO}_{3}{ }^{2-}>\mathrm{PO}_{4}{ }^{3-}$.
Thus, for the successful implementation of the sorption extraction of molybdenum from carbonate solutions, it. should contain the smallest possible amount of highly depressive impurities such as sulfate ion and products of incomplete oxidation of sulfur. Therefore, when processing raw materials containing a sufficient amount of sulfide minerals (up to 1-1.5\%), it is necessary to introduce the operation of sulfide flotation.

To prevent a significant accumulation of chlorine (nitrate) ions in the ion exchanger system, after regeneration, it should be washed with carbonate solutions as best as possible.

To confirm the obtained data, further studies should be carried out on the sorption of molybdenum from solutions containing all these anions under dynamic conditions. This will make it possible to bring the conditions of experience as close as possible to production processes.

\section{Acknowledgments}

This article was prepared as part of a master's thesis on "Extraction of molybdenum from leaching solutions of various compositions"

\section{References (GOST)}

1 Laverov N.P. (ed.) Underground leaching of polyelement ores [Podzemnoye vyshchelachivaniye polielementnykh rud]. - M.: Akademiya gornykh nauk. - 1998. - 446 pp. (In Russian)

2 Gazaleeva G.I., Klyushnikov A.M. On the issue of leaching of associated valuablecomponents during downhole underground leaching of uranium using oxidizing agents [K voprosu vyshchelachivaniya poputnykh tsennykh komponentov pri skvazhinnom podzemnom vyshchelachivanii urana s ispol'zovaniyem okisliteley] // Innovative technologies for the enrichment of mineral and industrial raw materials: materials of the V Ural Mining Forum. - Yekaterinburg: Publishing House of the Ural State Municipal University, 2013. - P.180-183. (In Russian)

3 Gromov O.B., Dyachenko A.N. Petov D.A., Seredenko V.A. Extraction of tungsten and molybdenum from uranium-containing solutions of the sublimation production waste recovery system [Izvlecheniye vol'frama i molibdena iz uransoderzhashchikh rastvorov sistemy regeneratsii otkhodov sublimatnogo proizvodstva] // Bulletin of the Tomsk Polytechnic University. Chemistry. 2011. - Vol.318. - P.37-40. (In Russian)

4 Gorbunov V.A., Litvinenko V.G. The development of uranium ore processing technology of the Streltsov group of deposits [Razvitiye tekhnologiy pererabotki uranovykh rud Strel'tsovskoy gruppy mestorozhdeniy] // Mining Journal. - 2018. - Vol.7. - P.5558. (In Russian)

5 Valiyev K.H., Bugubayeva A.U., Amandykova A.B., Bulayev K.H. Leaching of Uranium and Molybdenum from the Ore of the Vostok Deposit [Vyshchelachivaniye urana i molibdena iz rudy mestorozhdeniya «Vostok»] // Notes of The Tula State University. Earth Sciences [Izvestiya Tul'skogo Gosudarstvennogo Universiteta. Nauki O Zemle]. - 2019. - Vol.4. - P.92-98. (In Russian)

6 Zagorodnyaya A.N., Abisheva Z.S., Sharipova A.S., Sadykanova S.E., Bochevskaya Y.G., Atanov O.V. Sorption of rhenium and uranium by strong base anion exchange resin from solutions with different anion compositions// Hydrometallurgy. - 2013. Vol.131/132. - P.127-131.

7 Shokobaev N.M. Search for alternative effective ion exchangers for the extraction of uranium from productive solutions of underground borehole leaching [Poisk al'ternativnykh effektivnykh ionitov dlya izvlecheniya urana iz produktivnykh rastvorov podzemnogo skvazhinnogo vyshchelachivaniya] // Mining Journal of Kazakhstan [Gornyi zhurnal Kazakhstana]. - 2014. - Vol.8. P.30-37. (In Russian)

8 Akhunova A.A. Anion-exchange sorption of uranium (VI) from concentrated carbonate solutions of salts [Anionoobmennaya sorbtsiya urana (VI) iz kontsentrirovannykh karbonatnykh rastvorov soley] // Letters of St. Petersburg State Technological Institute (Technical University) [Izvestiya Sankt-Peterburgskogo Gosudarstvennogo Tekhnologicheskogo Instituta (Tekhnicheskogo Universiteta)]. - 2014. - Vol. 23. - P. 13-15. (In Russian)

9 Peganov V.A., Molchanova T.V., Smirnov K.M. Sorption processes in the technology of hydrometallurgical processing 
of molybdenite concentrates [Sorbtsionnyye protsessy $v$ tekhnologii gidrometallurgicheskoy pererabotki molibdenitovykh kontsentrato] // Non-Ferrous Metals [Tsvetnye Metally]. - 2010. - Vol.12. - P.56-59. (In Russian)

10 Bogdanova N.F., Frolova D.A. Sorption of molybdenum by anion exchangers from model and industrial solutions [Sorbtsiya molibdena anionitami iz model'nykh i promyshlennykh rastvorov] // Bulletin of St. Petersburg University. Physics and Chemistry [Vestnik Sankt-Peterburgskogo Universiteta. Fizika I Khimiya]. - 2012. - Vol. 1. - P.96-101. (In Russian)

11 Lasheen T.A., El-Ahmady M.E.,. Hassib H.B., Helal A.S. Hydrometallurgical routes to recovery of molybdenum from ores and mineral raw materials // Mineral Processing and Extractive Metallurgy Review. - 2014. - Vol.36. - P.145-173.

12 Shalchian H., Ferella F., Birloaga I. Recovery of molybdenum from leach solution using polyelectrolyte extraction // Hydrometallurgy. - 2018. - Vol.190. - P.218-225.

13 Turaev N.S., Zherin I.I. Chemistry and Technology of Uranium: Textbook for High Schools [Khimiya i tekhnologiya urana: Uchebnoye posobiye dlya vuzov]. - Moscow, 2005. - 407 pp.

14 Sharipov H.T., Sharafutdinov U.Z. The process of bicarbonate underground leaching of uranium from high-carbonate ores // Universum: Engineering: electron. scientific journal. - 2016. - Vol.9. - P.30.

\section{References}

1 Laverov NP (ed.) (1998) Underground leaching of polyelement ores [Podzemnoye vyshchelachivaniye polielementnykh rud]. Akademiya gornykh nauk, Moscow, Russia. ISBN 5-7892-0026-5. (In Russian)

2 Gazaleeva GI, Klyushnikov AM (2013) On the issue of leaching of associated valuable components during downhole underground leaching of uranium using oxidizing agents [K voprosu vyshchelachivaniya poputnykh tsennykh komponentov pri skvazhinnom podzemnom vyshchelachivanii urana s ispol'zovaniyem okisliteley]. Proceedings of Scientific Technical Conference "Innovative technologies for the enrichment of mineral and industrial raw materials: materials of the V Ural Mining Forum". Publishing House of the Ural State Municipal University, Yekaterinburg, Russia. P.180-183. (In Russian)

3 Gromov OB, Dyachenko AN Petov DA, Seredenko VA (2011) Bulletin of the Tomsk Polytechnic University. Chemistry 318:37-40.

4 Gorbunov VA, Litvinenko VG (2018) Mining Journal 7:55-58. http://doi.org/10.17580/gzh.2018.07.10

5 Valiyev KH. Bugubayeva AU, Amandykova AB, Bulayev KH (2019) Notes of The Tula State University. Earth Sciences [Izvestiya Tul'skogo Gosudarstvennogo Universiteta. Nauki O Zemle] 4:92-98. (In Russian)

6 Zagorodnyaya AN, Abisheva ZS, Sharipova A S, Sadykanova S E, Bochevskaya Y G, Atanova OV (2013) Hydrometallurgy 131132:127-131. http://doi.org/10.1016/j.hydromet.2012.11.003

7 Shokobaev NM (2014) Mining Journal of Kazakhstan [Gornyi zhurnal Kazakhstana] 8:30 -37. (In Russian)

8 Akhunova AA (2014) Letters of St. Petersburg State Technological Institute (Technical University) [Izvestiya SanktPeterburgskogo Gosudarstvennogo Tekhnologicheskogo Instituta (Tekhnicheskogo Universiteta)] 23:13-15. (In Russian)

9 Peganov VA, Molchanova TV, Smirnov KM (2010) Non-ferrous metals [Tsvetnye Metally] 12:56-59. (In Russian)

10 Bogdanova NF, Frolova DA (2012) Bulletin of St. Petersburg University. Physics and Chemistry [Vestnik Sankt-Peterburgskogo Universiteta. Fizika I Khimiya] 1:96-101. (In Russian)

11 Lasheen TA, El-Ahmady ME, Hassib HB, Helal AS (2014) Min Proc Ext Met Rev 36:145-173. https://doi.org/10.1080/0882750 8.2013.868347

12 Shalchian H, Ferella F, Birloaga I (2018) Hydrometallurgy 190:218-225. https://doi.org/10.1016/j.hydromet.2019.105167

13 Turaev NS, Zherin II (2005) Chemistry and Technology of Uranium: Textbook for High Schools [Khimiya i tekhnologiya urana: Uchebnoye posobiye dlya vuzov]. Moscow, Russia. (In Russian)

14 Sharipov HT, Sharafutdinov UZ (2016) Universum: Engineering: electron. scientific journal 9:30. 